\title{
Victims' Rights Looking Good on Paper - How Criminal Prosecution in Germany Fails Victims of Sexual Violence
}

\author{
Anne-Katrin Wolf ${ }^{1}$ and Maja Werner ${ }^{2}$ \\ ${ }^{1} \mathrm{H} 2 \mathrm{~W}$ Strafrecht, Berlin, Germany, and ${ }^{2}$ Department of Public Law, Max Planck Institute for the Study of Crime, Security and \\ Law, Freiburg, Germany. \\ Corresponding author: wolf@h2w-strafrecht.de
}

(Received 12 July 2021; accepted 12 July 2021)

\begin{abstract}
Whether in Germany or abroad, victims of sexual violence typically played only a minor part in criminal proceedings, serving primarily as witnesses due to the widespread public and objective nature of the trial. ${ }^{1}$ This led to victim disempowerment and a paternalistic method of State protection of victims. ${ }^{2}$ During the last decades, this perception underwent major changes in European legal systems, owing to a rising awareness of victim's needs, especially in cases of sexual violence. ${ }^{3}$ International and European conventions and treaties played a major role ${ }^{4}$ by establishing an international regulatory framework. To implement those international standards, domestic criminal laws have changed significantly on both substantive and procedural levels. Today, Germany's criminal procedure law contains many mechanisms for protecting victims. Nevertheless, in cases of sexual violence, the implementation of these mechanisms in criminal proceedings leaves much to desire due to the affect of gender stereotypes and rape myths. This Article argues that in these cases the law in action ultimately fails to meet international requirements.
\end{abstract}

Keywords: Sexual Violence; Gender-based Violence; Victim Rights; Victim Protection; Criminal Prosecution; Private Accessory Prosecution

\footnotetext{
${ }^{1}$ Wolfram Schädler, Opferschutz in der deutschen straf- und strafprozessrechtlichen Gesetzgebung und dessen Umsetzung in die Judikatur, in Ambivalenzen der Opferzuwendung des STRAFrechts 51 (Stephan Barton \& Ralf Kölbel eds., 2012); Stephanie Bock, Opferrechte im Lichte europäischer Vorgaben, in AMBIVALENZEN DER OPFERZUWENDUNG DES STRAFRECHTS 67 (Stephan Barton \& Ralf Kölbel eds., 2012); Heike Jung, Zur Renaissance des Opfers - ein Lehrstück kriminalpolitischer Zeitgeschichte, 33 ZRP 159, 159 (2000); see generally Michael Kilchling, Opferschutz und der Strafanspruch des Staates - Ein Widerspruch?, 22 NSTZ 57 (2002); for a rather philosophical analysis of the system in France and the U.S., see generally Janine Barbot \& Nicolas Dodier, (Sarah-Louise Raillard trans.), Rethinking the Role of Victims in Criminal Proceedings Lawyers' Normative Repertoire in France and the United States, 64 Revue FrançaISE DE SCIENCE POLITIQUE 407 (2014).

${ }^{2}$ Schädler, supra note 1, at 64; Jung, supra note 1, at 159.

${ }^{3}$ See generally Thomas Weigend, Internationale Entwicklungen bei der Stellung des Verletzten im Strafverfahren, in Ambivalenzen der Opferzuwendung des Strafrechts (Stephan Barton \& Ralf Kölbel eds., 2012).

${ }^{4}$ Additionally, civil actors such as NGOs and victim support groups as well as feminist movements had a strong affect. 


\section{A. International and European Law Shaping Victim Rights and Standing}

International law had, and still has, a large influence on national developments. ${ }^{5}$ This is true for various aspects of criminal procedure law and the rights of the accused, but international law also shapes the rights and standing of victims. ${ }^{6}$ In fact, it has paved the way towards more active participation of victims in German and European proceedings.

\section{The Victim as Subject in Public and Regional International Law}

At the start of their codification, human rights within criminal proceedings were primarily applied to protect the fragile position of the accused. This focus was easily justified: The significance of human rights to criminal law still seems obvious, as criminal law entails strong State powers and is by its very nature oppositional in interest to individuals. ${ }^{7}$ Accordingly, key human rights instruments focus in various ways on protecting the rights of the accused against State powers. ${ }^{8}$

By contrast, for a long time, ${ }^{9}$ criminal law's affect on the victim has seemed less obvious. Victims used to be perceived as mere bystanders with no unique procedural interest. The idea of a fair and impartial trial seemed not to apply to the victim in their role as a "neutral" witness, as they have often been regarded. ${ }^{10}$ Human rights instruments accordingly do not explicitly reference victims' rights. The word "witness(es)" appears—if at all—only in the context of rights of the accused towards the witnesses of the case-for example, Article 14, paragraph 2, subsection e of the International Convenant on Civil and Political Rights (ICCPR). Despite this lack of explicit mention, victims' rights are nonetheless now widely accepted as human rights. ${ }^{11}$ The victim of a crime is protected by human rights if they are under a legal obligation to be a part of the trial ${ }^{12}$ such as a witness in Germany. According to procedural rights, such as the right of recognition before law and effective remedy seen in Article 6 UDHR, Article 13 ECHR, and Article $47^{13}$ of the EU Charter of Fundamental Rights, ${ }^{14}$ victims must also not be treated as mere evidence but as subjects in the criminal trial. ${ }^{15}$ In addition, Article 8 ECHR protects the intimate sphere of the victim within a criminal trial. ${ }^{16}$

\footnotetext{
${ }^{5}$ The strong influence of those international instruments becomes particularly clear when authoritarian regimes reject treaties or threaten to withdraw, see, as an example, the recent developments in Turkey; see generally AMNESTY INTERNATIONAL, TURKeY: CONVENTION ON COMBATING VIOLENCE AGAinst WOMEN MUST BE IMPLEMENTED NOT ABANDONED, Aug. 5, 2020, https://www.amnesty.org/en/latest/news/2020/08/turkey-convention-on-combating-violence-against-women-must-be-implementednot-abandoned/.

${ }^{6}$ Mehmet Gürcan Daimagüler, Der Verletzte im Strafverfahren 309-25 (2016).

${ }^{7}$ P.H.P.H.M.C. van Kempen, Criminal Law and Human Rights xi, xviii (2014).

${ }^{8}$ Jo-Anne Wemmers, Victims Rights are Human Rights: The Importance of Recognizing Victims as Persons, 15 TEMIDA, 71, 72 (2012).

${ }^{9}$ Weigend, supra note 3 , at 30 .

${ }^{10} I d$. at 30; this is also true for the German legal system, $c f$. Schädler, supra note 1, at 51.

${ }^{11}$ European Union Agency for Fundamental Rights, Victims' Rights as Standards of Criminal Justice - Justice for Victims of Violent Crime, Part I, at 10 (2019), https://fra.europa.eu/sites/default/files/fra_uploads/fra-2019-justice-for-victims-ofviolent-crime-part-1-standards_en.pdf.

${ }^{12}$ Jung, supra note 1 , at 162 (referring at least to a need for regulation of such a situation).

${ }^{13}$ For the meaning of Article 47 of the Charter of Fundamental Rights, see Agentur der Europäischen Union für Grundrechte und Europarat, Handbuch zu den europarechtlichen Grundlagen des Zugangs zur Justiz, at 173 (2016), https://www.echr.coe.int/Documents/Handbook_access_justice_DEU.PDF.

${ }^{14}$ Frank K. Peter, Verbesserung der Stellung des Opfers im StrafVerfahren 54 (2014); Daimagüler, supra note 6, at 309.

${ }^{15}$ Weigend, supra note 3, at 49-50; Bock, supra note 1, at 71-72; Wemmers, supra note 8, at 80; regarding Art. 6 ECHR Susanne Walther, Victims' Rights: Procedural and Constitutional Principles for Victim Participation in Germany, in Therapeutic JURISPRUdENCE AND VICTIM PARTICIPATION IN JUSTICE 97, 110 (Edna Erez et al. eds., 2011).

${ }^{16}$ Weigend, supra note 3 , at 48.
} 


\section{The Influence of EU Instruments}

Beyond these general rights, there is — at least for the European area-more differentiated regional international law. Influences of European instruments have been especially important for victims within German criminal proceedings, ${ }^{17}$ as they can claim different degrees of binding force and obligations of implementation than the above instruments. ${ }^{18}$

The EU first set minimum standards for protecting EU crime victims rather late by adopting the Council Framework Decision 2001/220/JHA of 15 March 2001 on the standing of victims in criminal proceedings, ${ }^{19}$ and the Council Directive 2004/80/EC of 29 April 2004 relating to compensation to crime victims. ${ }^{20}$

Directive 2012/29/EU ${ }^{21}$ broadened the scope of the Council Framework Decision 2001/220/ JHA and focused even more on victim needs. According to its Guidance Document, ${ }^{22}$ Member States should ensure that the national criminal justice system recognizes the victim as an individual with discrete needs, with a key role in criminal proceedings. ${ }^{23}$ The Directive entails specific measures for the protection of victims and provides a quasi-rights-based approach towards the victim. ${ }^{24}$

Rather recently, the European Parliament adopted a Resolution on the implementation of the Victims' Rights Directive on May 30, 2018 on the implementation of Directive 2012/29/EU ${ }^{25}$ to reestablish minimum standards on the rights, support, and protection of victims of crime. ${ }^{26}$ The Resolution noted inter alia that "women victims of gender-based violence always require special support and protection, owing to their particular vulnerability to secondary and repeat victimization" and that "in a considerable number of cases, the victim is the most important witness in the trial and needs to be protected from possible retaliatory or threatening behaviour from the offender, including by preventing repeated or secondary victimization." As one of the shortcomings in implementing the Victims' Rights Directive, the Resolution noted the missing guarantee of "rapid, efficient and victim-sensitive procedures in criminal court cases that take account of the specific needs of the most vulnerable groups."

\footnotetext{
${ }^{17}$ See generally Bock, supra note 1.

${ }^{18} I d$. at 68 .

${ }^{19}$ Council Framework Decision of Mar. 15, 2001 On the Standing of Victims in Criminal Proceedings, 2001/220/JHA, 2001 O.J. (L 82, 22); for the application, see ECJ, Case C-105/03, Criminal Proceedings Against Maria Pupino, 2005 E.C.R., I-05285, paras. 54, 57, 59, 61. See also Bock, supra note 1, at 74-76.

${ }^{20}$ Council Directive 2004/80/EC of Apr. 29, 2004, Relating to Compensation to Crime Victims, 2004 O.J. (L 261).

${ }^{21}$ Directive 2012/29/EU, of the European Parliament and of the Council of 25 Oct. 2012 Establishing Minimum Standards on the Rights, Support and Protection of Victims of Crime, and Replacing Council Framework Decision 2001/220/JHA, 2012 O.J. (L 315); for other victim related instruments, see Council Directive 2004/80/EC of 29 April 2004 Relating to Compensation to Crime Victims, 2004 O.J. (L 261); Directive 2011/92/EU, of the European Parliament and of the Council of 13 Dec. 2011 on Combating the Sexual Abuse and Sexual Exploitation of Children and Child Pornography, and Replacing Council Framework Decision 2004/68/JHA, 2011 O.J. (L 335); Directive 2011/36/EU, of the European Parliament and of the Council of 5 Apr. 2011 on Preventing and Combating Trafficking in Human Beings and Protecting its Victims, and Peplacing Council Framework Decision 2002/629/JHA, 2011 O.J. (L 101); Directive (EU) 2017/541, of the European Parliament and of the Council of 15 Mar. 2017 on Combating Terrorism and Replacing Council Framework Decision 2002/475/JHA and Amending Council Decision 2005/671/JHA, 2017 O.J. (L 88).

${ }^{22}$ DG Justice Guidance DocumentRelated to the Transposition and Implementation of Directive 2012/29/EU of the European Parliament and of the Council of 25 Oct. 2012 Establishing Minimum Standards on the Rights, Support and Protection of VIctims of Crime, and Replacing Council Framework Decision 2001/220/JHA, Ref. Ares(2013)3763804 (Dec. 19 2013), https://victimsupport.eu/activeapp/wp-content/uploads/2014/04/EC-Guidance-Document_Feb201411.pdf.

${ }^{23} I d$. at 7.

${ }^{24}$ European Union Agency for Fundamental Rights, supra note 11, at 22.

${ }^{25}$ European Parliament Resolution of 30 May 2018 on the Implementation of Directive 2012/29/EU, Establishing Minimum Standards on the Rights, Support and Protection of Victims of Crime, 2020 O.J. (C 76).

${ }^{26}$ Klaus Schroth \& Marvin Schroth, Die Rechte des Verletzten im Strafprozess 19-21 (3d ed. 2018).
} 


\section{The Istanbul Convention's Special Meaning}

Next to the European instruments, one of the most important international instruments regarding victims' rights is certainly the Council of Europe Convention on Preventing and Combating Violence Against Women and Domestic Violence ("Istanbul Convention"). This international treaty plays a particular role in preventing and combating sexual violence and also contains requirements relating to victims of gender-based violence. Compared to other international instruments, it contains specific guidelines on protecting against gender-based violence. It also defines violence against women so that is explicitly understood as violating human rights and a form of discrimination. ${ }^{27}$

The Istanbul Convention recognizes the structural nature of gender-based violence within the Member States and provides definitions that Member States must consider. "Violence against women" is accordingly defined as "all acts of gender-based violence that result in, or are likely to result in, physical, sexual, psychological or economic harm or suffering to women, including threats of such acts, coercion or arbitrary deprivation of liberty, whether occurring in public or in private life." ${ }^{28}$ Moreover, the Istanbul Convention's basic approach is to avoid stereotypes. Article 36 prescribes that States must ensure that interpretations of rape legislation and prosecutions in rape cases are not influenced by gender stereotypes and myths about male or female sexuality. ${ }^{29}$

The Istanbul Convention provides not only specific support mechanisms for victims of genderbased violence, including sexual violence, but also specific protection rules for victims within criminal law processes and rights towards perpetrators, such as a right to compensation. ${ }^{30}$ According to Articles 54 and 56, Member Parties shall take necessary precautions to protect victims within criminal proceedings. For example, evidence relating to the victim's sexual history and conduct is permitted only when it is both relevant and necessary, ${ }^{31}$ and victims and their families are ensured protection from intimidation, retaliation, and repeat victimization. ${ }^{32}$ Germany ratified the Istanbul Convention in 2018 and is thus obliged to implement these various requirements.

Furthermore, the Council of Europe (CoE) addressed the needs and interests of crime victims and their dependents from early on. Resolution 77 (70) prompted adoption of the European Convention on Compensation of Victims of Violent Crimes, which though not acknowledging the concept of a victim, obliged State parties to compensate victims of intentional and violent offences resulting in bodily injury or death. In 1985, another CoE Recommendation recognized that the criminal justice system's focus on the dual relation between State and offender tended to add problems for crime victims. ${ }^{33}$ Regarding the Convention, it stated that the victim's needs had to be considered at all stages of the criminal process. The Recommendation Rec (2006) of the Committee of Ministers to Member States on assistance to crime victims addressed three kinds of victim protections: 1) Protection of physical and psychological integrity; 2) protection against repeat victimization; and 3) protection of privacy. In detail, it states that particular protection may be necessary for victims who could be required to provide testimony and specific protection measures should be taken for victims at risk of intimidation, reprisals, or repeat victimization, including adequate training on repeat victimization and on ways to reduce such risks. These regulations are also binding on Germany.

\footnotetext{
${ }^{27}$ Convention on Preventing and Combating Violence Against Women and Domestical Violence, art. 3 (a), Nov. 2014.

${ }^{28} I d$.

${ }^{29} I d$. at art.36,

${ }^{30} I d$. at art. 30

${ }^{31} I d$. at art.54

${ }^{32} I d$. at art.56, para 1 .

${ }^{33}$ Council of Europe, Recommendation No. (85) 11, on the Position of the Victim in the Framework of Criminal Law and Procedure (1985); Bernd-Dieter Meier, Ein Überblick über die Gesetzesänderungen seit 1985, in OPFERRECHTE IM StrafVerfahren AUf DEM PRÜfSTAND 17 (Bertram Börner et al. eds., 2020).
} 


\section{Conclusion on International Influences on Victims' Rights}

In conclusion, at the level of international law, the role of the victim in criminal proceedings has become more active, and victims' rights have been strengthened in the light of international standards. As the drafters of the core human rights documents initially did not foresee needing to implement active victims' rights, subsequent international declarations and treaties had to fill the gap. The EU and the Council of Europe have set high standards regarding victims in criminal proceedings. Particularly, Directive 2012/29/EU and the CoE Istanbul Convention stipulate precise rules on how to protect victims of gender-based violence.

Those instruments also led to significant changes within German criminal law, both substantively and procedurally. ${ }^{34}$ The perception of victims no longer as "neutral" witnesses but as active parts of criminal proceedings as fashioned by international law is found in German law as the possibility of a private accessory prosecution (Nebenklage) as regulated in Sections 395-402 of the Code of Criminal Procedure (CCP). Through the possibility of a private accessory, the victim no longer has only the position of a witness in criminal proceedings, but receives further procedural rights, for example the right to be present (Anwesenheitsrecht), ${ }^{35}$ the right to request evidence (Beweisantragsrecht), ${ }^{36}$ or the right to ask questions (Fragerecht). ${ }^{37}$

International instruments focus also on aspects tending to receive less attention in the German system and will be addressed in the following review of German criminal procedure relating to various problems within the practice:

- Problem of gender stereotypes and the acceptance of the structural nature of gender-based violence;

- Problem of secondary and repeated victimization; ${ }^{38}$ and

- Psychological consequences of re-traumatization.

This Article does not argue that it is necessary to restrict the rights of the accused, for example by limiting his right to be present or to ask questions, in order to avoid the above-named problems. Rather, it argues that in Germany, there are practical implementation deficits that are independent from tension between the rights of the accused and victims, and that it is not consistent with international law if those practical deficits cause further victimization and re-traumatization.

\section{B. Victims' Rights in Germany: Rights on Paper versus Realization in Practice}

Beginning in the $1980 \mathrm{~s},{ }^{39}$ victim protection underwent significant changes in German criminal law, mainly by strengthening victim participation. ${ }^{40}$ Looking at the relevant procedural rules, the victim's role has certainly been strengthened. ${ }^{41}$ The criminal process is no longer limited to the State and the accused, and the victim's importance no longer reduced to providing a witness statement. ${ }^{42}$ Victims in Germany now have strong procedural rights. For example, they can join

\footnotetext{
${ }^{34}$ Schädler, supra note 1 , at 55 .

${ }^{35}$ Strafprozessordnung [StPO] [CODE OF Criminal Procedure], $₫ 397$, para. 1.

${ }^{36} I d$.

${ }^{37} I d$. at $\$ 244$, paras. $3-6$.

38“Secondary victimization" means insensitive, victim-blaming treatment that excarbates the trauma, for further references, see Rebecca Campbell, Rape Survivors' Experiences With the Legal and Medical System, 12 VIOLENCE AGAINST WOMEN 30, 31 (2006).

${ }^{39}$ Schädler, supra note 1 at 51; for a more detailed view on the development, see id. at 52-61; Rita Haverkamp, Im Labyrinth des Opferschutzes-Zum Entwurf eines Dritten Opferrechtsreformgesetzes, 48 ZRP 53, 53-55 (2015).

${ }^{40}$ For an overview concerning procedural rights, see SСнRотн \& SCHROTH, supra note 26, at 1-26.

${ }^{41}$ For an overview see Weigend, supra note 3 , at 42-48; JUTTA BADER, LEGITIME VerLetZTENINTERESSEN IM STRAVFERFAHREN 38-49 (2019).

${ }^{42}$ Bader, supra note 41 , at 46 .
} 
the process, ${ }^{43}$ retain legal counsel, ${ }^{44}$ or secure the services of a professional psychosocial assistant. $^{45}$

The position of victims in Germany, as outlined by the law, therefore appears to be overall in the interest of victim protection. Internationally, the Report of the European Union Agency for Fundamental Rights (FRA) mentions Germany as one of the few States where legislation acknowledges victims of violent crime as parties to the criminal proceedings. ${ }^{46}$ Likewise, some scientific contributions report similar results. ${ }^{47}$ Nevertheless, it would be a mistake to conclude that the actual and, above all, the psychological burdens that accompany criminal proceedings for victims have been reduced to a necessary minimum by the legal position. ${ }^{48}$ When it comes to evaluating the status of victims' rights, it is imperative to look beyond "paper rights" to any enduring practical problems victims of sexual violence continue to face in German courts.

Two such problems are examined in the following sections. First, criminal proceedings are influenced by rape myths and stereotypical role models, often to the disadvantage of female victims. Those myths and gender stereotypes often influence the way victims are perceived and treated, increasing the risk of secondary victimization and re-traumatization. Second, implementation deficits persist in the application of victim protection standards. These are often general problems, but in cases of sexual violence, they have particularly serious consequences for victims. Before those two problems are addressed, it is necessary to explain why those problems manifested within the field of sexual violence.

\section{Sexual Violence - an Example of Insufficient Realization}

As examined further below, the above-noted legal changes were only partially or not at all put into a larger social context. ${ }^{49}$ This has hindered and still hinders effective victim protection, especially for victims of sexual violence. This is because assumptions about sexual violence or about "typical" victim behavior still circulate all too freely within the criminal courts and influence criminal prosecution. $^{50}$

The problems that will be addressed in this subsection are not limited to only cases of sexual violence or abuse of women. Victims' experiences differ according to their race, sexual orientation, class, and all manner of previous experiences. But these problems become most apparent in cases of sexual violence for at least two reasons. First, there are difficulties in providing supporting evidence. ${ }^{51}$ Crimes of sexual violence are usually not witnessed by anyone other than the victim and the accused, ${ }^{52}$ which is why successful prosecutions are dependent on the victim's statement. ${ }^{53}$

\footnotetext{
${ }^{43}$ Strafprozessordnung [StPO] [COde of Criminal Procedure], $\$ 395$.

${ }^{44} I d$. at $\$ 406(\mathrm{f})$, para. 1 .

${ }^{45} \mathrm{Id}$. at $\$ 406(\mathrm{~g})$.

${ }^{46}$ European Union Agency for Fundamental Rights, supra note 11, at 9, 37 ("rights-based approaches and comprehensive participation rights.").

${ }^{47}$ Pardo-Valcarce Foundation, Comparative Legal Research, Rights and Protection of Vulnerable Victims in Criminal Proceedings 36-43 (2017), https://www.bienestaryproteccioninfantil.es/imagenes/tablaContenidos03SubSec/2017_Comparative \%20Legal\%20Research_UAVDI.pdf.

${ }^{48}$ Oliver Tolmein, Nebenklage-eine Erweiterung, keine Demontage des liberalen Strafverfahrens, in AMBIVALENZEN DER OpferZuWENdUNG DES STRAFRECHTS 242-245 (Stephan Barton \& Ralf Kölbel eds., 2012).

${ }^{49} \mathrm{Cf}$. Pilar Albertín Carbó et al., 15 Feminist Criminology 70, 73 (2020) (identifying the same problem for the Spanish criminal justice system in the context of measures against gender-based violence.)

${ }^{50}$ See generally Jennifer Temkin \& Barbara Krahe, SeXual Assault and the Justice Gap (2008); for the German Legal System, see e.g., Lena Stelzner \& Anne-Sophie Minuth, Genderstereotype in Sexualstrafverfahren, FORUM RECHT 89 (2018).

${ }^{51}$ Wiebke Steffen, Polizeiliches Verhalten bei Opfern von Sexualstraftaten am Beispiel der Opfer von Vergewaltigungen und sexuellen Nötigungen, in Ambivalenzen der Opferzuwendung Des Strafrechts 141 (Stephan Barton \& Ralf Kölbel eds., 2012).

${ }^{52} I d$. at 154.

${ }^{53}$ Steffen, supra note 51, at 148; Oona Brooks-Hay, Doing the "Right Thing"? Understanding Why Rape Victim-Survivors Report to the Police, 15 Feminist CRIMINOLOGY 174, 174-75 (2020).
} 
In circumstances where there is no evidence except the statements of the victim ("He Said, She Said"-Case, "Aussage gegen Aussage"), special importance is attached to the questioning of the victim. The questioning can be very problematic for the victim's psychological well-being. ${ }^{54}$ Therefore, in cases of sexual violence, victims are regularly exposed to particularly stressful situations. ${ }^{55}$ Second, in cases where rape myths and gender stereotypes come into play, ${ }^{56}$ genderstereotyped arguments have actually been used to influence the margin of appreciation of the court and the outcome of the trial. Rape myths are "descriptive or prescriptive beliefs about sexual aggression ... that serve to deny, downplay, or justify sexually aggressive behavior that men commit against women." ${ }^{57}$ This is also regarded as a problem in international perception, ${ }^{58}$ which is why this issue receives special attention in section II, subsection 1 below. $^{59}$

Additionally, another problem is revealed by taking a closer look at case outcomes: ${ }^{60}$ In 2018 , German prosecutors received about approximately 72,000 cases of sexual violence. The prosecutors submitted a bill of indictment ("Anklage") according to Section 170, paragraph 1 of the Criminal Code of Procedure in only 10,512 cases. In 31,698 cases the proceedings were terminated for lack of sufficient evidence. ${ }^{61}$ It is true that statistics show similar outcomes in other categories of crimes such as bodily harm, ${ }^{62}$ and that it seems difficult to identify the precise reasons for those decisions. ${ }^{63}$ However, the low level of sentencing reduces the willingness of victims of sexual violence to report it, ${ }^{64}$ so it is important to ask whether there are specific reasons for those outcomes concerning crimes of sexual violence at such an early stage of the proceedings-even before the

\footnotetext{
${ }^{54}$ Michael Kilchling, Bausteine für einen verbesserten Opferschutz jenseits des Strafprozesses, in OPFERRECHTE IM Strafverfahren auf Dem PrÜfstand 232 (Bertram Börner et al. eds., 2020).

${ }^{55}$ Renate Volbert, Geschädigte im Strafverfahren: Positive Effekte oder sekundäre Viktimisierung?, in AMBIVALENZEN DER OpFERZUWENDUNG DES STRAFRECHTS 198 (Stephan Barton \& Ralf Kölbel eds., 2012).

${ }^{56}$ Barbara Krahé, Soziale Reaktionen auf primäre Viktimisierung: Zum Einfluss stereotyper Urteilsmuster, in AMBIVALENZEN DER Opferzuwendung Des STRAFrechts 159-170 (Stephan Barton \& Ralf Kölbel eds., 2012).

${ }^{57}$ Heike Gerger et al., The Acceptance of Modern Myths About Sexual Aggression Scale: Development and Validation in German and English, 33 Aggressive BeHAVIour 422, 425 (2007).

${ }^{58}$ See generally Jean-Claude Juncker, Strengthening Victims' Rights: From Compensation to Reparation, For a New EU Victims' Rights Strategy, Council Doc. 8629/19 (2020), https://db.eurocrim.org/db/en/doc/3204.pdf; European Institute for Gender Equality, Forms of Violence (2020), https://eige.europa.eu/gender-based-violence/what-gender-based-violence/ forms-gender-based-violence; European Union Agency for Fundamental Rights, Challenges to Women's Human Rights in the EU 15 (2017), https://fra.europa.eu/sites/default/files/fra_uploads/fra-2017-challenges-to-women-human-rights_en.pdf; European Union Agency for Fundamental Rights, Violence Against Women: an EU-wide Survey 24 (2015), https://fra. europa.eu/sites/default/files/fra_uploads/fra-2014-vaw-survey-main-results-apr14_en.pdf with reference to Federal Ministry for Family Affairs, Senior Citizens, Women and Youth, Health, Well-being and Personal Safety of Women in Germany: A Representative Survey of Violence Against Women in Germany - Summary of the Central Research Results 9 (2004), https://www.bmfsfj.de/blob/84316/10574a0dff2039e15a9d3dd6f9eb2dff/kurzfassung-gewalt-frauen-data.pdf.

${ }^{59}$ Already here it must be noted that there is only little empirical knowledge about the behavior of the participants in Germany, $c f$. Steffen, supra note 1, at 141. Nevertheless, the empirical findings cause the problems discussed here to be taken seriously with regard to effective realization of victim rights.

${ }^{60}$ Statistisches Bundesamt, Rechtspflege Staatsanwaltschaften, Fachserie 10, Reihe 2.6, 56-59 (2018), https://www.destatis. de/DE/Themen/Staat/Justiz-Rechtspflege/Publikationen/Downloads-Gerichte/staatsanwaltschaften-2100260187004.pdf?_blob= publicationFile; Steffen, supra note 51, at 150. In general the figures concerning darkfield and conviction rate are discussed very controversial among researchers, see e.g., Deborah F. Hellmann \& Christian Pfeiffer, Epidemiologie und Strafverfolgung sexueller Gewalt gegen Frauen in Deutschland, 98 MsCHKRIM 527, 527-42 (2015); for a controversial view on the outcomes see Jutta Elz, Verurteilungsquoten und Einstellungsgründe, Was wissen wir tatsächlich?, in SEXUELLE GEWALT ALS Herausforderung FÜr GeSEllschaft und Recht 117-42 (Martin Rettenberger \& Axel Dessecker eds., 2017).

${ }^{61}$ Statistisches Bundesamt, supra note 60, at 56.

${ }^{62} I d$. at $64-67$.

${ }^{63}$ Krahé, supra note 56 , at 162.

${ }^{64}$ Sarah Seifert \& Heike Ludwig, Dunkelfeld und Anzeigeverhalten bei Delikten gegen die sexuelle Selbstbestimmung, 99 MschKRIM 237, 242 (2016).
} 
start of a trial. ${ }^{65}$ Such reasons could be multiple interviews, the conditions of interviews, the lack of professional support, and the lack of qualification of the interviewers. The fact that only five percent of women who experience sexual violence report it at all suggests that the investigation process in such cases is already fraught with difficulties and possibly influenced by stereotypes ${ }^{66}$ that discourage victims from filing complaints, and also influence the ensuing investigation. ${ }^{67}$

\section{Victim-Blaming, Gender Stereotyping and Rape Myths Influencing Criminal Proceedings of Sexual Violence}

With this in mind, one of the most overlooked problems within criminal proceedings is the widespread affect of rape myths and stereotypical role models.

\section{Influence of Gender Stereotypes and Rape Myths on the Treatment of Victims of Sexual Violence}

It is an established fact in psychologcial research that legal judgments are systematically influenced by prejudice, ${ }^{68}$ which is particularly a problem in cases of sexual violence. ${ }^{69}$ The legal regulations for victim protection do not change the influence of underlying concepts of gender stereotypes and rape myths on criminal proceedings. ${ }^{70}$ All too regularly, their effects may even lead to secondary victimization. ${ }^{71}$ The problem is exacerbated when the victim is the only witness, which raises the importance of the questioning of the victim and heightened susceptibility to stereotypes and misconception. ${ }^{72}$

There is a consensus among practitioners and researchers that stereotypical conceptions of rape shared by members of the criminal justice system play an important role in the treatment of victims. ${ }^{73}$ Initially problematic is the myth of "real" rape, according to which rape is committed by a foreign perpetrator, at night and in the open, and under the use or threat of physical violence, the victim then actively defends his- or herself, then immediately reports the incident and their injuries to the police. ${ }^{74}$ Cases that deviate from this pattern are often not perceived as "real" rape. ${ }^{75}$ However, the reality looks very different. For instance, only 14.5 percent of the perpetrators are unknown to the victim. ${ }^{76}$ In almost half of the cases the perpetrator is a partner or

\footnotetext{
${ }^{65}$ Krahé, supra note 56, at 162; Megan A. Alderden \& Sarah E. Ullman, Creating a More Complete and Current Picture: Examining Police and Prosecutor Decision-Making When Processing Sexual Assault Cases, 18 ViolenCE AgAINST WoMEN 525, 526 (2012).

${ }^{66}$ Federal Ministry for Family Affairs, Senior Citizens, Women and Youth, Health, Well-being and Personal Safety of Women in Germany: A Representative Survey of Violence Against Women in Germany-Langfassung TEIL I 180 (2004), https://www.bmfsfj.de/blob/84328/0c83aab6e685eeddc01712109bcb02b0/langfassung-studie-frauen-teileins-data.pdf; for a compilation and summary about the reasons of women not reporting see Brooks-Hay, supra note 53, at 175-76; see also Steffen, supra note 51, at 150-52.

${ }^{67} \mathrm{Cf}$. Steffen, supra note 51, at 148.

${ }^{68}$ Margit E. Oswald, Strafrichterliche Urteilsbildung, in LEHRBUCH DER RECHTSPSYCHOLOGIE 248 (Thomas Bliesener et al. eds., 2014).

${ }^{69} \mathrm{Cf}$. Krahé, supra note 56, at 159; Steffen, supra note 51, at 147 , (speaking here of a "fundamental distrust" ["grundsätzliches Misstrauen"] of the police).

${ }^{70}$ In detail about variable and heuristics of judicial judgement see Oswald, supra note 68, at 244-56.

${ }^{71}$ Debra Patterson, The Linkage Between Secondary Victimization by Law Enforcement and Rape Case Outcomes, 26 J. OF INTERPERSONAL VIOLENCE 328, 329 (2011). For a more general approach including further studies see Carbó et al., supra note 49 , at $74-75$.

${ }^{72} \mathrm{Cf}$. Steffen, supra note 51 , at 154 .

${ }^{73}$ TemKIn \& Krahé, supra note 50, at 31-51; Barbara Krahé et al., Prospective Lawyers' Rape Stereotypes and Schematic Decision Making About Rape Cases, 14 PsYCH., CRIME \& L. 461, 461-62 (2008); Krahé, supra note 58, at 159-70; Fiona Leverick, What Do We Know About Rape Myths and Juror Decision Making?, 24 INT'L J. of EvidENCE \& ProOF 255, 273 (2020).

${ }^{74}$ TEMKIN \& KRAHÉ, supra note 50, at 31-32; Krahé, supra note 56, at 160.

${ }^{75} \mathrm{Krahé} \mathrm{et} \mathrm{al.,} \mathrm{supra} \mathrm{note} \mathrm{73,} \mathrm{at} \mathrm{461-62;} \mathrm{Krahé,} \mathrm{supra} \mathrm{note} \mathrm{56,} \mathrm{at} \mathrm{160;} \mathrm{Leverick,} \mathrm{supra} \mathrm{note} \mathrm{73,} \mathrm{at} 273$.

${ }^{76}$ Federal Ministry for Family Affairs, Senior Citizens, Women and Youth, Health, Well-being and Personal Safety of Women in Germany: A Representative Survey of Violence Against Women in Germany-Part I 78 (2004), https://www. bmfsfj.de/resource/blob/84328/3bc38377b11cf9ebb2dcac9a8dc37b67/langfassung-studie-frauen-teil-eins-data.pdf.
} 
ex-partner. ${ }^{77}$ Studies have shown that this idea of "real" rape also influences the assessment of cases by lawyers, ${ }^{78}$ for example, as in cases where a partner is the perpetrator, fixing the perpetrator's responsibility as "lower" and the victim's complicity as "higher." ${ }^{\prime 2}$ Research also indicates that cases involving non-strangers are less likely to proceed. ${ }^{80}$ The fact that cases of sexual violence are discontinued can therefore also explain the fact that the investigation procedure is affected by this notion of "real" rape and the victim's responsibility in other cases. ${ }^{81}$

The fact that the crime was committed by a stranger or the ex-partner also influences expectations of victim reactions. For example, it is assumed that sexual violence by the partner is less traumatizing than such violence by a stranger, ${ }^{82}$ which in itself is a trivialization of the crime. Furthermore, there are also general expectations regarding the damage to the victim or how a victim "should" behave after a sexual assault, ${ }^{83}$ while in fact there are many factors that determine how they react and recover from victimization. ${ }^{84}$ This is problematic, because if the victim does not behave this way, it could be taken as an indication that the crime did not take place. ${ }^{85}$ Additionally, the victim's reactions during the questioning may be falsely interpreted as a result of underlying misconceptions of "typical reactions." ${ }^{66}$ There are several other rape myths which may influence the criminal process in a way that is detrimental to the victim, such as "she wanted it," "she deserved it," that "all rapists are insane" or "sex-starved," 87 and all of these can lead to a trivialization of the crime or to blaming of the victim.

The problem of such myths becomes even more intensified in cases that receive media attention. Negative media reports have a very strong affect on the victims of crime and can cause secondary victimization. ${ }^{88}$ Media attention also has a direct and indirect influence on those involved in the process, ${ }^{89}$ which is why in such cases gender stereotypes could be transported into the process by the media.

Additionally, other stereotypes on gender roles and role expectations ${ }^{90}$ may influence the perception of witness statements as well as the idea of the lying women. ${ }^{91}$ Studies have shown that the victim's moral character or their engaging in risk-taking behaviors influences perceptions of

\footnotetext{
${ }^{77}$ Id.; see also Steffen, supra note 51 , at 149.

${ }^{78} I$ d. at 32; TEMKIN \& KRAHÉ, supra note 50, at 80-82; Krahé, supra note 56, at 166 . For an overview of both quantitative and qualitative studies on this subject see Leverick, supra note 73, at 256-79.

${ }^{79}$ TEMKIN \& KRAHÉ, supra note 50, at 81; Krahé et al., supra note 73, at 469; Krahé, supra note 58, at 160.

${ }^{80}$ Patterson, supra note 71, at 330; for an overview see Alderden \& Ullmann, supra note 65, at 529-30.

${ }^{81}$ TEMKIN \& KRAHÉ, supra note 50, at 32; Patterson, supra note 71, at 329-30; see also Alderden \& Ullmann, supra note 65, at 529 , for further references to studies that indicate that cases with weapon presence and victim resistance are more likely to be prosecuted.

${ }^{82} \mathrm{With}$ further references, see in general for predictions concerning the relationship between victim and perpetrator SUSEN Werner, Stereotype Vorstellungen Über Vergewaltigungen (Vergewaltigungsmythenakzeptanz) als Prädiktoren der Beurteilung von VergewaltigungsdelikTen durch Rechtsanwältinnen 40 (2010).

${ }^{83}$ TEMKIN \& KRAHÉ, supra note 50, at 33.

${ }^{84}$ Patricia A. Resick, Psychological Effects of Victimization: Implications for the Criminal Justice System, 33 CRIME \& DELINQUENCY 468, 473 (1987); Schädler, supra note 1, at 61.

${ }^{85}$ Temkin \& Krahé, supra note 50 , at 32.

${ }^{86}$ Barbot \& Dodier, supra note 1, para. 27.

${ }^{87}$ Krahé, supra note 56, at 160-61. For further references for evey myths, see Tanja Purucker, Von zu kurzen Röcken und anderen Märchen. Vergewaltigungsmythen - Hintergründe, Folgen und eine Möglichkeit der Intervention 29-31 (2017), https://epb.bibl.th-koeln.de/frontdoor/deliver/index/docId/1012/file/Ausgezeichnet+2017+01+Purucker+++ Vergewaltigungsmythen.pdf.

${ }^{88}$ Hans Mathias Kepplinger \& Thomas Zerback, Der Einfluss der Medien auf Richter und Staatsanwälte, 54 PUB 216,229 (2009).

${ }^{89}$ Fourty six percent of judges and prosecuters share the opinion that media reports often or occasionally have an influence on the course of the entire procedure, for the testimonies of witnesses this is felt in seventy-six percent of cases, $c f$. Kepplinger \& Zerback, supra note 88, at 230.

${ }^{90}$ See also Carbó et al., supra note 49 , at 83 .

${ }^{91}$ For further references see Carbó et al., supra note 49, at 74.
} 
victim credibility in prosecutorial decision-making in cases of sexual assault. ${ }^{92}$ This indicates that gender expectations regarding sexual behavior may influence criminal proceedings. This can be demonstrated by the following excerpts from a police interrogation: The-female-police officer asked the victim, "You are 13 and have had sexual intercourse with numerous boys. What do you think, is this a normal behavior for you?" impression that [the victim] had no values at all. She seemed almost indifferent to how other people-especially boys - thought about her behavior." ${ }^{4}$ Here, a devaluation of the victim becomes apparent, ${ }^{95}$ based on a moral evaluation of her behavior and role expectations.

The same can be said for role expectations, when, for example, the fact that a woman does not assume her expected roles leads to disregarding violence in intimate relationship as gender-based violence. ${ }^{96}$ If those rape myths and gender stereotypes are not known or acknowledged by the deciding judges, it will be very easy within a statement-versus-statement scenario to deconstruct the witness statement. This is even more likely if the first interrogations were not conducted with the necessary sensitivity or if the victim has to face personal questions that are not consistent with the requirement to protect the victim's personal life and dignity.

According to the German Code of Procedure, there are neither specialized courts nor responsibilities for gender-specific violence. Nor are there any training obligations for judges to discharge, for example, victim-friendly interview techniques. Although today there are some specialized educational programs, ${ }^{97}$ it is up to the individual judge or state prosecutor whether he or she attends such a program. Therefore, it is not guaranteed that victims of sexual violence will be heard in front of specialized judges. As it has been shown, there is at least a serious risk that this may lead to receptivity to rape myths and gender stereotypes. This is problematic, especially with regard to the Istanbul Convention. In particular, Article 49, paragraph 2 of the Convention requires necessary measures to ensure that the prosecution of gender-based violence considers a gendered understanding of violence. In general, avoiding stereotypes in prosecuting gender-based violence plays a central role in the convention, as does effective criminal prosecution. Both requirements are undermined due to the described difficulties.

\section{Insufficient Sensitivity during Victim Interrogations}

During a criminal procedure in Germany, it is highly likely that victims are interrogated not only once or twice, but several times in several ways. Even at a first interrogation there are different challenges for victims. Interrogations of a victim are inevitable at some stages of a criminal procedure. Nevertheless, it would be appropriate to take more account of victims' rights here.

\subsection{Interrogation of the Victim by the Police}

The victim may be heard for the first time at the police station, and after those first interrogations, there might be subsequent further interrogations to clarify gaps or unclear information. ${ }^{98}$ The victim may meet different police officers until he or she finally is interrogated by a specialized unit. ${ }^{99}$ This is problematic because insufficient sensitivity of police officers can lead to problems in dealing with the victim, which risks re-traumatization. The presence of an attorney might help

\footnotetext{
${ }^{92}$ See also Alderden \& Ullmann, supra note 65, at 529.

${ }^{93}$ Weisser Ring, Stiftung, Belastungen von Opfern im ERmittlungSverfahren 31 (2017).

${ }^{94}$ Id. at $31-32$.

${ }^{95}$ Id. at 31 .

${ }^{96}$ Carbó et al., supra note 49 , at 83 .

${ }^{97}$ See e.g., DeUtSche Richter AKademie, JahreSPRogramm 2021 http://www.deutsche-richterakademie.de/icc/drade/nav/ $4 \mathrm{fc} /$ broker.jsp?uMen=eec31bbe-aa5d-3712-140c-a146350fd4c2.

${ }^{98}$ Weisser Ring, supra note 93, at 22-23.

${ }^{99}$ Lynne Goodstein \& Faith Lutze, Rape and Criminal Justice Response, in The ChangIng Role OF WOMEN IN THE Criminal Justice System 169 (Imogene L. Moyer ed., 1992); Steffen, supra note 53, at 147 (stating the importance of the police as first interrogators).
} 
in such situations to protect the rights of the victim. But, in a lot of cases the victim will be informed of the right to have an attorney present just after the interrogation started and will rather go on with it than ending it to find an attorney. Additionally, the attorney might also risk an allegation to have influenced the victim if the attorney takes an overly dominant role during the questioning.

In "He Said, She Said" situations where no further evidence is present, the first interrogations may have a significant influence on trial outcomes. In such situations, the court will later submit the statement of this witness to a special plausibility test, ${ }^{100}$ the so-called analysis of consistency. For this analysis, the first interrogations of the victim are of huge importance as later contradictions may lead to a denial of credibility. ${ }^{101}$ To avoid such contradictions it is not only necessary to minimize the number of interrogations but also to analyze and consider any special victim needs, such as lack of knowledge, the ability to express herself or himself, communication, and learning disabilities or psychiatric diagnoses.

Furthermore, at this first stage of the investigation process, but also in later criminal proceedings, rape myths and role expectations can influence judgments about the victim's credibility. ${ }^{102}$ Assuming that the victim wanted or deserved it is a myth expressing a tendency towards blaming the victim in cases of sexual violence. ${ }^{103}$ It has also been shown that blaming women for precipitating sexual assaults is an all too common aspect of legal decision-making. ${ }^{104}$

Overall, there is a high risk of secondary victimization during interrogations, ${ }^{105}$ which explains why victims of sexual assaults shy away from reporting them to the police. ${ }^{106}$ To avoid secondary victimization and minimize undesirable effects on the victim, the interrogation has to take place in certain settings and by trained personnel. ${ }^{107}$ In addition, there were efforts to improve the handling of victims of sexual violence by the police. ${ }^{108}$ However, standards vary tremendously between the federal states and even cities within one federal state. For example, in Berlin, there are specialized police forces that are working only on workdays until 7:30 pm. ${ }^{109}$ Whether a victim is interrogated by a specialized police officer basically depends upon the time of the crime. ${ }^{110}$ Specialized police officers or better trained personnel in general would also increase the willingness of victims to report crimes to the police. ${ }^{111}$ Based on empirical findings, it can also be assumed that victims of sexual violence shy away from filing charges because they fear that their credibility with the police will be questioned, ${ }^{112}$ which is actually often the case in cases of sexual

\footnotetext{
${ }^{100}$ Established jurisprudence, see for references Klaus Miebach, Die freie Beweiswürdigung der Zeugenaussage in der neueren Rechtsprechung des BGH, 21 NSTZ-RR 329, 329 (2016).

${ }^{101}$ Sabine Nowara, Welche Faktoren beeinträchtigten Opfer im Strafverfahren?, in OPFERRECHTE IM STRAFVERFAHREN AUF DEM PRÜFSTAND 124 (Bertram Börner et al. eds., 2020).

${ }^{102}$ For the spanish legal system see Carbó et al., supra note 49, at 79; with regard to police officers see Alderden \& Ullmann, supra note 65, at 527; Patterson, supra note 71, at 330; Steffen, supra note 53, at 147.

${ }^{103} \mathrm{Cf}$. Steffen, supra note 51, at 154; Patterson, supra note 71, at 335.

${ }^{104}$ For further references, see Krahé et al., supra note 73, at 1786; Steffen, supra note 53, at 154; for a review see generally TEMKIN \& KRAHÉ, supra note 50.

${ }^{105}$ In summary, see Patterson, supra note 71 , at 329-30.

${ }^{106}$ Seifert \& Ludwig, supra note 65, at 241; Patterson, supra note 71, at 329; Steffen, supra note 53, at 155.

${ }^{107}$ Patterson, supra note 71 , at 343 .

${ }^{108}$ Steffen, supra note 51 , at $144-47$.

${ }^{109}$ Katja Füchsel, Opferschutzbeauftragter wirft der Polizei Versagen vor, July 25, 2020, https://www.tagesspiegel.de/ gesellschaft/tausende-sexualdelikte-bleiben-ungesuehnt-opferschutzbeauftragter-wirft-polizei-und-justiz-versagen-vor/ 2603j5118.html.

${ }^{110} \mathrm{Cf}$. Weisser Ring, supra note 93, at 165. For experiences of victims in Germany, see e.g., EUROPEAN UNION AGENCY FOR Fundamental Rights, WOMEN AS VICTIMS OF PARTNER VIOLENCE-JUSTICE FOR VICTIMS OF VIOLENT CRIME, PART IV 40 (Apr. 25, 2019) https://fra.europa.eu/sites/default/files/fra_uploads/fra-2019-justice-for-victims-of-violent-crime-part-4women_en.pdf.

${ }^{111}$ Seifert \& Ludwig, supra note 64, at 241.

${ }^{112} I d$.
} 
violence. ${ }^{113}$ In this respect, an unprofessional approach to initial contact with the victim is also a reason why crimes against sexual self-determination cannot be effectively prosecuted. ${ }^{114}$

These risks and gaps regarding a victim-sensitive approach are particularly problematic given Article 56, paragraph 1 of the Istanbul Convention, which requires appropriate measures to protect victim interests, including the investigation procedure. This also includes adequate police training. In addition, Article 50, paragraph 2 of the Istanbul Convention, although basically referring to prevention, also includes the collection of evidence. In this respect, it can be concluded that the standards supported by the Istanbul Convention also refer to the gathering of evidence through interrogations. In addition, the Istanbul Convention generally demands that the structural nature of sexual violence be recognized and that efforts be made to ensure that stereotypes do not lead to gender-based violence being perceived as acceptable. Regarding those requirements, it would be important and appropriate to allocate financial resources for further police training and victim psychosocial support by trained social workers for police interrogations. ${ }^{115}$

\subsection{Interrogation of the Victim by the Court}

Even if the victim was interrogated by a specialized police force, this specialization ends in Court. There are no specialized courts in Germany that deal only with cases of sexual violence.

The Code of Criminal Procedure sets certain standards for interrogations to protect victim privacy, but those standards are, inevitably, open to interpretation. ${ }^{116}$ Section $68(\mathrm{a})$ of the German Code of Criminal Procedure aims to protect witnesses and is of special importance in cases of sexual violence. According to Section 68(a) Code of Criminal Procedure, not only shall personal questions be avoided, but questions concerning private and intimate life will be admissible only after careful examination of their indispensability. ${ }^{117}$

Nevertheless, in the case of sexual offences, detailed questions about the previous sexual life of victim witnesses may still not be prevented because of the large margin of appreciation of Section 68(a) of the German Code of Criminal Procedure and judicial fears of potential grounds for a revision of the case. ${ }^{118}$ The margin of appreciation permits perceptions of victims and gender stereotypes that can lead to a less effective protection of victims in court. ${ }^{119}$ This becomes apparent looking at the scientific commentaries that are often used by judges for interpretive assistance. For example, one famous commentary, last revised in 2014, reads, that in certain contexts of sexual violence it may be relevant to "determine how the victim behaved sexually towards the accused or third parties before and after the crime. The victim's behavior before and after the crime and in general in previous partnerships can have indicative value and then require clarification; accordingly, it is not uncommon for the accused to claim that it was a matter of consensual sexual contact and/or that the prosecution witness "seduced" (verführt) him." 120

Regardless of the form or aim of such interrogations, questions about the sexual behavior of the victim constitute serious encroachments on the intimate sphere. In addition, the cited remarks indicate the risk of an essentializing view of the victim's behavior in partnerships, which then possibly leads to a trivialization of the crime in the eyes of the judges, if the offender is an

\footnotetext{
${ }^{113}$ Weisser Ring, supra note 93, at 163.

${ }^{114} \mathrm{Cf}$. Dean G. Kilpatrick \& Randy K. Otto, Constitutionally Guaranteed Participation in Criminal Proceedings for Victims: Potential Effects on Psychological Functioning, 34 WAYNe L. Rev. 7, 7 (1988); Alderden \& Ullmann, supra note 65, at 544, with references to further studies about the affects of negative experiences when reporting assaults to the police.

${ }^{115} \mathrm{Cf}$. Seifert \& Ludwig, supra note 65 , at 243; for an overview of the current measures, see Steffen, supra note 51, at 144-47.

${ }^{116}$ Weigend, supra note 3 , at 39-40.

${ }^{117}$ Bundesgerichtshof [BGH] [Federal Court of Justice] Jan. 11, 2005, NeUE JuRISTISChe WoChENSCHRIFT [NJW] 1519, 1520-1521, 2005. See also BT-Drs. 10/5305, Apr. 10, 1986, 10 (the reasoning within the legislation procedure).

${ }^{118}$ Weigend, supra note 3, at 39-40; Deutscher Juristinnenbund, Opferrechte in Strafverfahren wegen geschlechtsbezogener Gewalt, at 8.

${ }^{119}$ Juncker, supra note 58, at 30, 31.

${ }^{120}$ MÜKoSTPO/MAIER, STPO, $\$ 68 \mathrm{a}$, para. 9 (2014) (with reference to Bundesgerichtshof [BGH] [Federal Court of Justice], Case No. 2 StR 149/90, 1990, NStZ 400, (Apr. 4, 1990)).
} 
(ex-)partner. In cases of sexual violence by the partner, there is a tendency to blame the victim for the act. ${ }^{121}$ The assumption that the victim may have "seduced" the perpetrator represents a massive victim-blaming view of the offence. As studies have shown, victims of sexual violence tend to blame themselves in any case. ${ }^{122}$ Questioning with the aim of determining whether the victim is partly responsible for the crime can intensify such feelings in a way that can be dangerous for the victim's psychological well-being. Of course, there is a tension between the protection of the victim and the presumption of innocence, which cannot be resolved without putting a strain on the victim. For this reason, special training for judges on how to deal sensitively with these interrogation situations is essential regarding psychological health after traumatic experiences. ${ }^{123}$ Article 54 of the Istanbul Convention requires that the interrogation of a victim's sexual history and behavior is admitted only if it is both relevant and necessary. In any case, judges are therefore urged to limit questioning about sexual behavior to what is absolutely necessary, and it must be carried out with sensitivity, particularly with regard to the protection of the victim's private sphere demanded in Article 8 ECHR. ${ }^{124}$

\section{Practical Obstacles of Addressing the Needs of Victims of Sexual Violence}

Besides the above-identified misconceptions and their influence, victim well-being highly depends upon how well practitioners apply the given standards. German criminal procedure law provides important mechanisms for protecting victims' interests. In particular, the possibility of a private accessory prosecution helps victims play a more active role. Unfortunately, however, factual obstacles lead to these standards being applied without taking into account the high international standards of victim protection. This is especially true in view of the consequences of these general problems for victims of sexual violence.

\section{Reality of Joint Prosecution in Court}

As mentioned, one of the most important instruments for victims is the joint prosecution ("Nebenklage"), ${ }^{125}$ which allows victims of sexual violence to assume a more active part within the trial. ${ }^{126}$ The joint prosecution implies various rights according to the Code of Criminal Procedure, ${ }^{127}$ such as to be present at the main hearing even if the victim is to be examined as a witness or to make statements during the trial. ${ }^{128}$

Nevertheless, it is sometimes not possible for victims to exercise these rights effectively. ${ }^{129}$ First, the joint prosecution is not a necessary part of the trial in contrast to the accused and his or her lawyer. Therefore, even though the victim who joins the prosecution has a right to be present in the main hearing together with his or her lawyer, the Court is not obliged to coordinate the dates of the main hearing with the victim or his or her lawyer. ${ }^{130}$ Thus, it depends upon the good will of the Court to include the joint prosecution when it sets the dates. ${ }^{131}$ Practitioners have explained

\footnotetext{
${ }^{121}$ For further references to other empirical studies, see Krahé et al., supra note 74, at 1793.

${ }^{122}$ Seifert \& Ludwig, supra note 64, at 241; Weisser Ring, supra note 93, at 83.

${ }^{123}$ Resick, supra note 84 , at 473 .

${ }^{124}$ Bundesgerichtshof [BGH] [Federal Court of Justice], Jan. 11, 2005, NeUE JURISTISCHE WochenSCHRIFT [NJW] 1519, 1520 ; see also Schädler, supra note 1 , at 57-58.

${ }^{125}$ Strafprozessordnung [StPO] [Code of Criminal Procedure], $\$ 395$.

${ }^{126}$ Daimagüler, supra note 6, at 75; Wolfgang Rosenbusch, Erfahrungen aus der Schwurgerichtskammer, in OPFERRECHTE IM StrafVerfahren AUf DEM PRÜFSTAND 34 (Bertram Börner et al. eds., 2020).

${ }^{127}$ StrafproZessordnung [StPO] [COde of Criminal Procedure], $\$ \$ 395-402,406 \mathrm{e}$.

${ }^{128} I d$. at $\$ \$ 257,395$.

${ }^{129}$ Tolmein, supra note 48 , at $235-244$.

${ }^{130}$ Henriette Lyndian, Analyse der Wirklichkeit von Opferrechten im Strafprozess, in OPFERRECHTE IM STRAFVERFAHREN AUF DEM PRÜFSTAND 69-71 (Bertram Börner et al. eds., 2020).

${ }^{131}$ Petra Ladenburger, Strukturelle und praktische Defizite der institutionalisierten Opferhilfe in Deutschland, in Ambivalenzen der Opferzuwendung Des Strafrechts 297 (Stephan Barton \& Ralf Kölbel eds., 2012).
} 
that due to this lack of coordination with victims and their counsel, victims will sometimes not be able to appear in court with the lawyer that has worked on the case since inception. ${ }^{132}$ Second, the right to information about the trial may be undermined without further consequences. ${ }^{133}$ The same is true when it comes to plea deals according to Section 257(c) of the Code of Criminal Procedure. Such deals usually include a confession of the accused that will lead to a reduction of the sentence. For such a deal, the consent of the prosecutor and the accused is needed, while the joint prosecution has no right to veto such a deal. ${ }^{134}$ Although non-prosecution is unlikely in cases of sexual violence, the same is true in cases of non-prosecution subject to imposition of conditions and directions under Section 153(a) of the Code of Criminal Procedure.

Problems also arise concerning the right of the victim that joined the prosecution to inspect the case file ("Akteneinsicht"), which gives the victim the right to inspect the file of the particular case and thus to inform herself or himself about the entire proceeding. According to Section 406e, paragraph 1 of the Code of Criminal Procedure, a lawyer representing the joint prosecution may inspect the files which are available to the court or the files which would need to be submitted if public charges were preferred and she or he may view items of evidence in official custody. According to paragraph 2, file inspections shall be refused if there are overriding interests meriting protection, either on the part of the accused or of other persons. The provision seeks to balance data protection, defense interests, truth-finding, functional interests of the criminal justice system, and the legitimate, constitutionally derived right of the injured party to information. ${ }^{135}$ In the end, the decision is at the discretion of the court. For cases in which the victim provides the only evidence, the case law has developed contradicting outcomes over the last years. ${ }^{136}$ Although the Federal Court of Justice stated in 2016 that file inspections by a victim's lawyer does not necessarily lead to a devaluation of the statement, ${ }^{137}$ the right to inspection may still fully or partially be denied depending on the individual state prosecutor or judge. ${ }^{138} \mathrm{~A}$ full or even a partial denial of the right to inspect files diminishes the named rights of the joint prosecution. ${ }^{139}$ The lawyer representing the victim is in those circumstances unable to prepare questions or requests for evidence. $^{140}$

In sum, despite the human rights-based approach of victims' rights and especially the articles from section one ascribing to the victim an active role in the criminal process, guaranteed further by the possibility of joint prosecution, these shortcomings effectively undermine this position. For example, Article 56, paragraph 1 (d) Istanbul Convention requires victims be given the opportunity to present evidence and express concerns and needs. This may be formally guaranteed by the possibility of joint prosecution, but here too it is evident that it is equally important to raise awareness among the users of the law.

\footnotetext{
${ }^{132} I d$.

${ }^{133} I d$. at 298.

${ }^{134}$ Tolmein, supra note 48 , at 244.

${ }^{135}$ KK-STPO/ZABECK, STPO $\$ 406$ e, para. 5; Bundesverfassungsgericht [BVerfG] [Federal Constitutional Court], Jan. 31, 2017, NeUe JURISTISCHE WOCHENSCHRIFT [NJW] 1164.

${ }^{136}$ For further references to the case law see Daimagüler, supra note 6, at 39-41.

${ }^{137}$ Bundesgerichtshof [BGH] [Federal Court of Justice] Case No. 5 StR 40/16, NStZ 367 (Apr. 5 2016,); see also Kammergericht [KG] Case No. 3 Ws 278/18, NStZ 2019, 110, 111-112 (Nov. 21, 2018).

${ }^{138}$ Those decisions may refer to Oberlandesgericht Hamburg [OLG], Oct. 24, 2014, Case No. 1 Ws 110/14, BeckRS 2015, 700; see also MÜKoSTPO/GraU StPO, $\$ 406$ e, para. 14 (2019). For a critical approach towards the right to inspect court files, see generally Jesko Baumhöfener et al., Die Aktenkenntnis des Verletzten in der Konstellation Aussage-gegen-Aussage, 37 NSTZ 562 (2017). For the resulting contradiction with the Istanbul Convention, see HEIKE RABE\& BRITTA LEISERING, DiE IsTANBULKONVENTION 50 (2018), https://www.institut-fuer-menschenrechte.de/fileadmin/user_upload/Publikationen/ANALYSE/ Analyse_Istanbul_Konvention.pdf.

${ }^{139}$ Lyndian, supra note 130 , at 67.

${ }^{140}$ Heinz Schöch, Warum Opferrechte im Strafprozess wahrgenommen werden müssen?, in OPFERRECHTE IM Strafverfahren Auf Dem Prúfstand 180 (Bertram Börner et al. eds., 2020).
} 


\section{Use of Video Recordings to Avoid Second Interrogations}

The Criminal Code of Procedure provides possibilities to use audio and video recordings ${ }^{141}$ in order to protect the victim. Section 58(a) of the Code of Criminal Procedure provides the possibility of video and audio recording the statement of the victim to avoid several examinations of the victim. ${ }^{142}$ Since the last reform of the Code of Criminal Procedure Section 58(a), paragraph 1, sentence 3 states that the

hearing must be recorded after an assessment of the circumstances relevant in each case and must be conducted as a judicial hearing if the interests worthy of protection of persons who have been violated by offences against sexual self-determination (Articles 174 to 184 j of the Criminal Code) can be better safeguarded and the witness has consented to the audio-visual recording before the hearing.

This new sentence brought quite a change for victims as it includes adult victims of sexual violence and gives only a limited margin of appreciation. Section $58(\mathrm{~b})$ of the Code of Criminal Procedure provides the possibility of an examination by way of audio-visual transmission. In this way, the witness does not have to face the perpetrator while giving his or her statement. Therefore, on mere paper, the victim seems to be protected against several questionings by the police, the state prosecution, and the court; also, the victim does not have to face the perpetrator while making a statement. ${ }^{143}$

Looking at the practical implementation of those articles, it depends upon the possibilities within every federal state whether a victim has access to the safeguard measures that the Criminal Code of procedure provides. ${ }^{144}$ It has been shown that video recording is still used only very rarely due to insufficient financial or technical resources. ${ }^{145}$ Using Berlin as a recent example, the ratio of rule and exception is reversed. Since the beginning of 2020, despite the public prosecutor's office making over one hundred requests for video interviews, ${ }^{146}$ only a dozen video and audio recordings were made. The actual possibility of a video recording does not yet mean that it will be used. This must be applied for, whereby victims may encounter serious practical obstacles. ${ }^{147}$

It is clear here that the relevant provisions of the Code of Criminal Procedure are not applied in a way that best minimizes risks to victims' health associated with criminal proceedings. After all, the possibility is prescribed by law, but is insufficiently guaranteed by practice. ${ }^{148}$ In all those cases in which there is no possibility of video interrogation due to demonstrated lack of resources, the state's duty to protect, which is behind the criminal procedure regulations, is implemented in a deficient manner that also appears problematic in light of international standards. This already follows from Article 56, paragraph 1 (g) and (i) of the Istanbul Convention. This clearly shows that it is not only a matter of implementing the Convention on paper, but also of equipping the courts in such a way that implementation is possible. At the same time, it is important to increase the

\footnotetext{
${ }^{141}$ Susanne Claus, Zur Modernisierung des Strafverfahrens, 40 NSTZ 57, 63-64 (2020).

${ }^{142}$ See generally Sabine SWoboda, Videotechnik im StrafVerfahren (2002).

${ }^{143}$ Weigend, supra note 3, at 41.

${ }^{144}$ Volbert, supra note 55, at 203; Weisser Ring, supra note 93, at 165-66.

${ }^{145}$ Henrik Vogel, Erfahrungen mit dem Zeugenschutzgesetz 119-25 (2003); Maike Scheumer, Videovernehmung

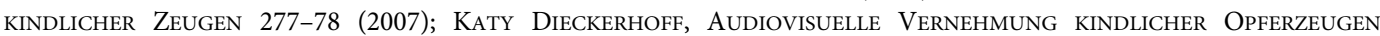
SEXUELLEN MissbraUCHS IM STRAFVERFAHREN 145-46 (2008); Weisser Ring, supra note 93, at 165-66.

${ }^{146}$ Katja Füchsel, Opferschutzbeauftragter wirft der Polizei Versagen vor, July 25, 2020, https://www.tagesspiegel.de/ gesellschaft/tausende-sexualdelikte-bleiben-ungesuehnt-opferschutzbeauftragter-wirft-polizei-und-justiz-versagen-vor/ 26035118.html.

${ }^{147}$ Tolmein, supra note 48 at $235-40$.

${ }^{148} \mathrm{Id}$. at $243-44$.
} 
judges' awareness of the fact that the video hearing must be given priority in order to prevent the victim and perpetrator from meeting.

\section{Excessive Length of Proceedings as a Reason for Exceptional Psychological Stress}

A very relevant problem, not exclusive to cases of sexual violence, is the length of criminal proceedings. Despite various changes to the procedural process, the criminal law process remains highly inefficient. ${ }^{149}$

The average duration of proceedings in the first instance before Germany's regional courts amounts to 19.4 months - from first notification of the public prosecutor's office. ${ }^{150} 30.8$ percent of the total number of proceedings exceeded eighteen months in length. ${ }^{151}$ It may not only lead to a much higher burden for the victim but can also result in a sentence reduction. ${ }^{152}$ It is likely that the long duration of procedure can lead to exceptional psychological stress for victims. ${ }^{153}$ During the trial, a victim is often unable to find closure. Especially in cases of sexual violence, the length of procedure can cause serious harms for the victim's psychological well-being. Victims of sexual assault often develop a post-traumatic stress disorder, ${ }^{154}$ have a slower rate of recovery than victims of other types of crime; ${ }^{155}$ rape victims in particular have various serious psychological impairments. ${ }^{156}$ Therefore, early and effective therapy and preventing secondary victimization is important for rape victims' well-being. ${ }^{157}$ However, many of those affected do not want to begin with psychological therapy during the duration of the criminal proceedings, as this can be seen in court as falsifying their testimony. ${ }^{158}$ Police and even lawyers may therefore often advise against therapy, because it might be used against the victim. ${ }^{159}$ This can lead to long-term negative mental health consequences. ${ }^{160}$ Therefore, victims might be stuck in a process of victimization until the end of trial.

In view of the ECtHR's case law, in which Convention violations have been assumed to have occurred owing to the duration of criminal proceedings, ${ }^{161}$ such cases cannot be classified as human rights violations per se. Similarly, the Istanbul Convention requires States Parties in Article 49 to ensure that judicial proceedings are not conducted without unjustified delay. Nevertheless, with regard to one of the essential requirements of international law, namely to limit psychological stress and risks of re-victimization to the absolute minimum, excessively long proceedings represent a central challenge in fulfilling international requirements. In fact, it would be desirable to have expedited trials in precisely those riskier cases that the international standards try to ameliorate. ${ }^{162}$ That is to say, employ expedited trials where the circumstances of the crime and the victim's mental health pose significant risk that their mental well-being might be seriously impaired by lengthier proceedings.

\footnotetext{
${ }^{149}$ Claus, supra note 141 , at 57; Katja Grieger \& Christina Clemm \& Anita Eckhardt \& Anna Hartmann, "Was

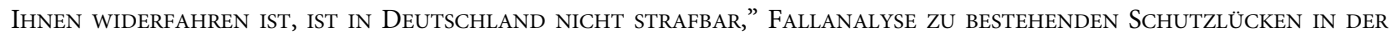
ANWENDUNG DeS DEUTSCHEN SeXUALSTRAFrechts BEZÜGLICH ERWACHSENER BETROFFener 26 (2014).

${ }^{150}$ Statistisches Bundesamt, supra note 60 , at 77.

${ }^{151} I d$.

${ }^{152}$ MÜKoStGB/Maier, StGB, $\$ 46$, para. 396 (2020).

${ }^{153}$ See generally Volbert, supra note 55.

${ }^{154}$ Ursula Gasch, Psychotherapie vor Abschluss der Beweisaufnahme im Strafverfahren?, KRIMINALISTIK 734, 736 (2018); Jörg Ziercke, Worauf kommt es den Opfern an? Wie werden die Anliegen durch die Beteiligung/Einbindung in den Strafprozess berücksichtigt?, in Opferrechte Im Strafverfahren auf Dem PrÜfstand 101 (Bertram Börner et al. eds., 2020).

${ }^{155}$ Resick, supra note 84 , at 476 .

${ }^{156} \mathrm{Id}$. at $469-70$.

${ }^{157}$ Patterson, supra note 71, at 343; Schrothm \& Schroth, supra note 26, at 29.

${ }^{158}$ Gasch, supra note 154, at 736; Weisser Ring, supra note 93, at 97.

${ }^{159}$ Miebach, supra note 100 , at 333.

${ }^{160}$ Patterson, supra note 71 , at 343.

${ }^{161}$ Wienholtz v. Germany, Eur. Ct. H.R., Case No. 974/07 (2010), http://hudoc.echr.coe.int/fre?i=001-139457.

${ }^{162}$ Volbert, supra note 55, at 203.
} 


\section{Conclusion: Realization of Victims' Rights in Light of International Standards}

As we have seen, despite German laws providing various procedural safeguards for mitigating victim experiences during criminal trials, their implementation and use in cases of sexual violence has fallen short of international law standards. Adjustments to the criminal process that can alleviate the victim's situation include expedited trials, interviews by specially trained personal and necessary measures to avoid repeated questioning, all of which can be realized without restricting the rights of the accused. The main issue is therefore applying these legal alternatives consistently. In addition, the Istanbul Convention's formal commitment to avoiding stereotypes inhibiting effective prosecution of sexual violence needs to be firmly put into practice. Equally, it is essential to raise awareness among those who apply the law, particularly judges, if the standards of international conventions are to be reached in the future.

Anne-Katrin Wolf Anne-Katrin Wolf works as a lawyer at H2W Strafrecht in Berlin, Germany and is specialized in criminal law. She studied law in Berlin (Humboldt-Universität zu Berlin), London (LL.M., King's College London) and Paris (Maîtrise, Paris II). For her $\mathrm{PhD}$ she researched standing requirements of UN human rights treaties.

Maja Werner Maja Werner works as a doctoral researcher at the Department of Public Law, Max Planck Institute for the Study of Crime, Security and Law, Freiburg, Germany.

Cite this article: Wolf A-K, Werner M (2021). Victims' Rights Looking Good on Paper — How Criminal Prosecution in Germany Fails Victims of Sexual Violence. German Law Journal 22, 800-816. https://doi.org/10.1017/glj.2021.43 